\title{
KONSEP KEPEMILIKAN ASSET TETAP DALAM AKUNTANSI SYARIAH
}

\author{
Ramdany \\ ${ }^{1}$ STIE Muhammadiyah Jakarta, ramdany2012@gmail.com
}

\begin{abstract}
ABSTRAK
Allah SWT adalah pemilik harta yang mutlak seperti dijelaskan dalam Al-Qur'an surat An Nisa, 132 menjelaskan : "Dan kepunyaan Allah apa yang ada dilangit dan dibumi”. Kemudian dalam surat Al-Baqarah ayat 29 disebutkan: "Dia-lah Allah, yang menjadikan segala sesuatu yang ada di bumi untuk kamu."Harta yang dimiliki oleh manusia adalah titipan dari Allah SWT dan kepemilikandan penggunaan harta oleh individu bersifat terbatas. Sedangkan kepemilikan harta dalam konvensional bersifat tidak terbatas dan hanya dibatasi oleh undang-undang serta etika moral dalam penggunaannya. Capra (2001:26) mengatakan bahwa dalam Islam tidak ada pemisahan antara kehidupan materil (dunia) dengan spritual ("in spite of its emphasis on moral, Islam does not recognize any watertight distinction between the material and the spiritual"). Dalam pengertian yang tersebut dapat disimpulkan akuntansi syariah adalah bagian dari Islam spritual itu sendiri. Jadi dapat diartikan kepemilikan asset dalam akuntansi syariah mengikuti sistem aturan yang berlaku dalam syariah Islam itu sendiri. Pencatatan dan pelaporan asset tetap dalam akuntansi syariah wajib mengikuti kaedah syariah yang telah ditetapkan dan akan dibahas dalam artikel ini.Termasuk didalamnya zakat atas asset tetap perusahaan.
\end{abstract}

Kata Kunci: Kepemilikan, asset, harta, akuntansi syariah, zakat perusahaan.

\begin{abstract}
Allah SWT is the absolute owner of property as explained in the Qur'an An-Nisa, 132 explains: "And belongs to God what is in the sky and on earth". Then in the Surah Al-Baqarah verse 29 it says: "He is Allah, Who made everything on earth for you." Treasures owned by humans are entrusted by Allah SWT and ownership and use of property by individuals are limited. Whereas conventional ownership of property is unlimited and is only limited by laws and moral ethics in its use. Capra (2001: 26) says that in Islam there is no separation between material (world) and spiritual life ("in spite of its emphasis on morals, Islam does not recognize any watertight distinction between the material and the spiritual"). In that sense it can be concluded that sharia accounting is part of spiritual Islam itself. So it can be interpreted as ownership of assets in sharia accounting following the system of rules that apply in Islamic sharia itself. Recording and reporting of fixed assets in sharia accounting must follow the established sharia method and will be discussed in this article. Includes zakat on fixed assets of the company.
\end{abstract}

Keywords: Ownership, assets, assets, sharia accounting, corporate alms 


\section{PENDAHULUAN}

Setiap orang diberikan kebebasan untuk memiliki harta. Islam mengakui seseorang untuk memiliki harta seperti yang dijelaskan dalam Quran (Al Hadid : 7) : "dan nafkahkanlah sebagian dari hartamu yang Allah telah menjadikan kamu menguasainya". Kepemilikan harta oleh individu sipatnya terbatas dalam arti bahwa harta itu hakekatnya adalah milik Allah SWT. Rahman (314:1995) menyatakan bahwa tanah dan segala sesuatu yang lain yang bersifat universal seperti ini termasuk milik Allah SWT dan manusia diberi hak untuk memanfaatkannya dengan kemampuannya sebagai "wakil Allah" dimuka bumi dan mempunyai hak menggunakan tanah (benda-benda lainnya) sepanjang tidak membahayakan kepentingan masyarakat.Qardhawi (1997:39) terjemahan, mengatakan " apabila setelah itu seorang muslim memperoleh harta, maka harta tersebut adalah harta Allah".Kepemilikan harta diakui Islam sepanjang harta tersebut tidak membahayakan masyarakat, termasuk didalamnya kepemilikan atas tanah, bangunan, kendaraan, peralatan, dan asset yang lainnya dan kesemua harta yang dimiliki oleh muslim adalah milik Allah SWT.

Allah adalah pemilik harta yang mutlak seperti dijelaskan dalam Quran surat An Nisa, 132 menjelaskan: "Dan kepunyaan Allah apa yang ada dilangit dan dibumi”. Harta yang dimiliki oleh manusia adalah titipan dari Allah SWT dan memberikan konsekuensi bahwa memilik harta harus bertanggungjawab dalam menggunakannya dikemudian hari.Pertanggungjawaban penggunaan harta dijelaskan dalam hadist Rasulullahbersabda: "Tidak akan bergeser dua telapak kaki seorang hamba pada hari kiamat sampai dia ditanya (dimintai pertanggungjawaban) tentang umurnya kemana dihabiskannya, tentang ilmunya bagaimana dia mengamalkannya,tentang hartanya; dari mana diperolehnya dan ke mana dibelanjakannya, serta tentang tubuhnya untuk apa digunakannya" (HR. At-Tirmidzi).

Allah adalah sebagai pemilik tunggal semua harta yang ada dimuka bumi ini. Manusia lahir tidak membawa harta apapun, juga pada saat meninggal dunia. Harta didapat pada saat manusia lahir adalah harta warisan dan pada saat meninggal dunia meninggalkan harta sebagai warisan kepada penerusnya (ahli waris). Allah berfirman dalam surat Yunus, 14 : "Kemudian kami jadikan pengganti-pengganti (mereka) dimuka bumi ini sesudah mereka, supaya Kami memperhatikan bagaimana kamu berbuat".Kalau diartikan dengan keterbatasan pengetahuan penulis bahwa tidak ada harta yang dimiliki oleh manusia karena manusia akan mati digantikan dengan yang lainnya, yang kekal hidupnya hanya Allah SWT. Oleh karena itu Allah adalah pemilik mutlak dari semua harta dunia dan alam semesta ini.

\section{KAJIAN LITERATUR}

\section{Kepemilikan Asset Tetap Dalam Akuntansi Syariah}

Harta dalam akuntansi lebih dikenal dengan istilah asset. Asset itu sendiri terdiri dari harta (aktiva) lancar (antara lain kas, piutang, persediaan) dan aktiva tetap (misalnya tanah, mesin, peralatan). Persamaan akuntansi menyatakan bahwa asset sama dengan hutang ditambah dengan modal.

Islam mengakui kepemilikan asset (harta) secara pribadi dan hanya mengijinkan penggunaannya untuk kemashalatan (kebaikan) saja. Allah berfirman dalam Al-Quran (AnNisaa':29) : “ Janganlah kamu saling memakan harta sesamamu dengan jalan yang batil”. Kepemilikan mutlak atas asset (harta) ada ditangan Allah SWT seperti firman-Nya dalam AlQuran (Yunus: 55): "Sesungguhnya kepunyaan Allah apa yang ada dilangit dan di bumi".Selanjutnya Allah menegaskan bahwa harta yang ada pada manusia adalah milik Allah, seperti dalam surat An Nur (ayat 33) Allah berfirman : "Dan berikanlah kepada mereka sebagian harta Allah yang dikaruniakan Nya kepadamu." Makna yang tersirat adalah bahwa harta yang ada pada diri manusia adalah kepunyaan-Nya, harta yang ada dimanusia hanya merupakan titipan dari Allah SWT dan dalam harta tersebut terdapat hak orang lain.

Kalau asset (harta) didunia ini merupakan milik Allah SWT, lalu bagaimana pengakuan asset tersebut dalam perusahaan?. Allah SWT berfirman (Al-Baqarah: 29) : “Dia-lah Allah yang menjadikan segala yang ada dibumi untuk kamu". Dalam Al-Quran surat An-Najm: 48, Allah 
SWT berfirman :"Dan bahwasanya Dia yang memberikan kekayaan dan memberikan kecukupan". Dapat diartikan bahwa manusia dapat memiliki sesuatu (kekayaan) yang ada dimuka bumi ini karena pemberian dari Allah SWT. Manan (1997:65, terjemahan) secara hukum hak memiliki individu adalah hak untuk memiliki, menikmati, dan memindah tangankan kekayaan yang diakui dan dipelihara dalam Islam, tetapi mempunyai kewajiban moral untuk menyedekahkan hartanya, karena kekayaannya itu juga merupakan hak masyarakat bahkan hewan.

Asset tetap (fixed asset) dapat dimiliki oleh perusahaan dengan cara jual beli, sewa beli (leasing), hibah atau pemberian cuma - cuma (hadiah), barang tidak bertuan. Transaksi kepemilikan asset tetap harus memenuhi syarat transaksi syariah yakni persaudaraan, keadilan, kemashalatan, kesimbangan dan universalisme (www.fighIslam.com)

Prinsip persaudaraan bahwa transaksi tersebut merupakan harmonisasi kepentingan, saling menolong dan memberikan manfaat. Prinsip keadilan menyatakan tempatkan sesuatu pada tempatnya, memberikan sesuatu kepada yang berhak untuk menerimanya. Implementasi dari keadilan adalah prinsip muamalah yang melarang adanya unsur riba, zalim, maysir, gharar dan haram. Prinsip kemashalatan menekankan pada unsur kepatuhan syariah (halal) serta bermanfaat dan membawa kebaikan (thayyib) dalam semua aspek. Prinsip kesimbangan menyatakan adanya kesimbangan misalnya antara materi dengan spritual, privat dengan publik, sektor keuangan dengan sektor riil, kepentingan bisnis dengan sosial serta pemanfaatan dan pelestarian. Prinsip universalisme artinya dapat dilakukan oleh siapa saja oleh pihak-pihak yang berkepentingan (stakeholders) dengan tidak membedakan suku, agama, ras dan golongan sesuai dengan semangat kerahmatan semesta (rahmatan lil alamin).

Jadi dalam akuntansi syariah asset tetap diakui apabila memenuhi persyaratan syariah dalam memperolehnya dan bukan didapat dari unsur-unsur yang melanggar aturan syariah.Ketentuan Al-Quran dan Al-Sunnah mengenai pengaturan kepemilikan kekayaan yang adalah sebagai berikut (Sularno, 1993) :

1) Pemanfaatan

Nabi SAW bersabda : "Orang yang menguasai tanah yang tak bertuan, tidak lagi berhak atas tanah itu jika setelah tiga tahun menguasainya, ia tidak menggarapnya dengan baik."

2) Penunaian Hak

Setiap muslim yang memiliki kekayaan mencukupi nisab, harus menunaikan zakat sesuai aturan syara'.

3) Tidak Merugikan Orang Lain

Penggunaan milik yang berfaedah ditujukan untuk mendatangkan manfaat bagi pemiliknya, namun tidak dibenarkan jika dalam penggunaannya menghadirkan madarat bagi pihak lain, merugikan pihak lain berarti pula meremehkan Allah, sebab Allah adalah pemilik segala sesuatu.

4) Kepemilikan Secara Sah

Al-Qur'an maupun Al-Sunnah melarang semua tindakan untuk memperoleh harta/milik dengan cara melawan hukum, karena hal ini menjadi sumber kerusakan

5) Penggunaan Berimbang

Pemilik harta benda dalam pandangan syariat harus menggunakannya secara berimbang, yakni jangan boros dan jangan kikir

Menurut Taheri (2001), perbedaan mendasar antara kapitalis dengan syariah adalah dalam prinsip kepemilikan. Asset dalam kepemilikan akuntansi konvensional mutlak sebagai milik pribadi. Kepemilikan publik bila diperlukan untuk kebutuhan sosial saja. Sedangkan dalam Islam asset (kekayaan) harus tersebar disemua lapisan masyarakat dan tidak dikuasai secara monopoli. Allah berfirman (Al-Hasyr : 7): " Harta itu jangan beredar diantara orang-orang kaya saja diantara kamu". 


\section{Akuntansi Syariah}

Nurhayati (2011:2) mendifinisikan akuntansi syariah adalah proses akuntansi atas transaksi-transaksi yang sesuai dengan aturan yang telah ditetapkan oleh Allah SWT. Mirza dan Baydoun (1999:5), mengatakan bahwa bisnis orang muslim menggunakan aturan Islam termasuk akuntansi juga mengikuti aturan Islam: "In an Islam society, parties to business transactions are expected to enter into contracts that conform to the Islamic Shari'a. Accounting in a society exists to reflect the business practices of that society; it has little use otherwise."

Akuntansi merupakan sistem informasi (Kieso, 2011:80). Kieso menyatakan: An accounting information system collects and processes transaction data and then disseminates the financial information to interest parties". Dapat diartikan secara umum bahwa akuntansi adalah informasi sistem yang mengumpulkan dan memproses data transaksi dan memberikan informasi keuangan kepada pihak yang berkepentingan.

Capra (2001:26) mengatakan bahwa dalam Islam tidak ada pemisahan antara kehidupan materil (dunia) dengan spritual ("in spite of its emphasis on moral, Islam does not recognize any watertight distinction between the material and the spiritual"). Dalam pengertian yang tersebut dapat disimpulkan akuntansi syariah adalah bagian dari Islam spritual itu sendiri.

Wan Ismail (2001) dalam Harahap (2001:108) mengemukakan akuntansi Islam itu sangat perlu bagi ummat Islam disebabkan adanya beberapa faktor:

1. Adanya konsep personal accountability antara manusia dengan Allah dan antara manusia dengan manusia

2. Adanya konsep dimana kekayaan adalah, harta adalah milik Allah. Manusia hanya selaku penerima amanah yang harus mempertanggungjawabkan penggunaannya kepada Allah SWT. Oleh karenanya maka pemanfaatannya harus sesuai dengan syariah

3. Perlunya proses distribusi kekayaan yang adil melalui zakat

Sedangkan tujuan dasar dari pelaporan keuangan akuntansi syariah menurut Triyuwono (2002b) dalam Aji (2006:87) adalah yang bersifat materi adalah untuk memberikan informasi (akuntansi), sedangkan bersifat spirit adalah untuk akuntabilitas. Posisi akuntabilitas lebih substansial, atau menjadi jiwa/etika dari pada memberian informasi.

Jadi dapat disimpulkan bahwa akuntansi syariah adalah sistem informasi yang mencatat, mengklasifikasikan, mengikhitisarkan transaksi keuangan menjadi informasi keuangan untuk pihak-pihak yang berkepentingan berdasarkan syari'ah Islam, termasuk pencatatan atas kepemilikan asset berdasarkan syari'ah.

\section{Pelaporan Asset Tetap Dalam Akuntansi Syariah}

AAOIFI (1998:24) dalam Harahap (2001:6)menyatakan : Dimulai dari tujuan akuntansi kontemporer, lakukan pengujian, lalu terima yang sesuai dengan syariat Islam dan tolak yang bertentangan dengan syariat Islam.Hal senada juga dikemukan oleh Ahmed (1990) dalam Adnan (89:2005) menyatakan : " ......... the Islamic approach is very near to the western approach in so far as the application of accounting conventions and principles is concerned. Accounting postulates of monetary measurement, going concern, realisation; accounting concepts of the business entity, objectivity, fairness, concistency, materiality, concervatism or prudence, and disclosure; and accounting principles of matching, cost and dual espects, all apply to the Islamic approach."

Pelaporan aktiva tetap dalam akuntansi syariah sama dengan pelaporan yang telah dilakukan dalam akuntansi konvensional. Aktiva tetap dilaporkan dalam neraca dan mempunyai nilai penyusutan.Perbedaan pelaporan antara asset tetap antara akuntansi syariah dan akuntansi konvensional adalah terletak pada filosofi (aturan) yang mendasari pencatatan atas asset (harta) tetap tersebut. Dalam akuntansi syariah pencatatan asset tetap harus sesuai dengan kaedah syariah yaitu asset tersebut diperoleh dari transaksi yang halal termasuk zatnya. Perolehan asset tetap tidak mengandung riba, zalim, maysir, gharar dan haram, dan yang terpenting aturan dalam akuntansi syariah secara keseluruhan berlandaskan Al-Quran dan Hadist Rasullulah dan pendapat para alim ulama. 
Semua transaksi perusahaan dicatat sesuai aturan syariah termasuk pencatatan asset tetap. Allah berfirman (Al-Baqarah:282): "Dan hendaklah seorang penulis diantara kamu menuliskannya dengan adil dan jaganlah seorang penulis enggan menuliskannya sebagaimana Allah telah mengajarkannya "Adil dalam pengertian ayat tersebut dapat diartikan bahwa pencatatan dalam akuntansi syariah bebas dari hal-hal yang merugikan orang lain dan berlandaskan aturan yang telah diberlakukan. Kaidah figh menyatakan "tidak dibolehkan seseorang bertindak atas harta benda orang lain, kecuali setelah mendapat izin pemiliknya". (Burhanuddi, 2011:85)

Ayat tersebut melandasi bahwa pencatatan yang dilakukan dalam akuntansi harus berlandaskan keadilandan kebenaran dimana asset yang dicatat tersebut benar-benar milik perusahaan yang sah dan dari transaksi yang halal seperti yang dipersyaratkan oleh Allah SWT dalam firmannya : "Dan janganlah kamu memakan harta sesamamu dengan bathil dan kamu bawa perkaranya kepada hakim supaya kamu dapat memakan sebagian harta orang lain dengan cara berbuat dosa sedangkan kamu mengetahuinya"(Al-Baqarah : 188). Dalam surat Al-Maidah ayat ke-8, Allah berfirman : "Hai orang-orang yang beriman hendaklah kamu jadi orang-orang yang menegakkan kebenaran karena Allah, menjadi saksi yang adil."

Sedangkan dalam akuntansi konvensional pencatatan asset tetap tidak mengenal aturan tersebut. Aturan yang ada dalam pencatatan asset tetap akuntansi konvensional berlandaskan aturan yang dibuat manusia berdasarkan logika dan kepentingan. Pencatatan akuntansi konvensional condong untuk kepentingan pemilik modal seperti yang diungkapkan oleh Harahap (2001:24), mengatakan bahwa akuntansi konvensional hanya untuk kepentingan pemilik modal (kapitalis). Hal ini bertentangan prinsip syariah dan dalam hal pencatatan aktiva tetap di akuntansi syariah harus memenuhi syarat syariah yaitu, (Mannan, 1997:65, terjemahan) :

1. Pemanfaatan Kekayaan

Dalam Islam tidak diperbolehkan memiliki kekayaan yang tidak digunakan. Rasullulah bersabda : "Siapa saja yang mengerjakan tanah tidak bertuan akan lebih berhak atas tanah itu". (HR. Bukhari). Artinya asset yang dimiliki perusahaan benar-benar asset yang bermanfaat bagi perusahaan itu sendiri maupun bagi masyarakat pada umumnya.

2. Pembayaran Zakat

Pemilik kekayaan pribadi harus membayar zakat sebanding dengan kekayaan yang dimilikinya. Bahwa asset yang tercatat dalam pembukuan perusahaan secara keseluruhan telah dizakatkan dalam zakat perusahaan.

3. Penggunaan yang berfaedah

Harta benda pribadi memberi manfaat kepada masyarakat secara keseluruhan untuk mendatangkan kemakmuran dan kesejahteraan. Bahwasanya asset yang tercatat adalah asset yang mendatangkan manfaat (keuntungan) bagi semua pihak.

4. Penggunaan yang tidak merugikan

Islam memberikan tekanan pada pemakaian harta benda yang berfaedah berarti membebankan kewajiban pada pemilik harta benda untuk menggunakan sedemikian rupa sehingga tidak mendatangkan kerugian bagi orang lain atau masyarakat. Tentunya asset yang dimiliki perusahaan tidak merugikan kepentingan apapun termasuk kepentingan masyarakat (umum), lingkungan dan kelangsungan kehidupan manusia.

5. Pemilik yang sah

Semua tindakan untuk memperoleh harta benda dengan cara-cara melawan hukum dilarang. Allah SWT berfirman (An-Nisa: 29): "Hai orang-orang yang beriman janganlah kamu saling memakan harta sesamamu dengan jalan yang batil, kecuali dengan jalan perniagaan yang berlaku dengan suka sama suka diantara kamu." Asset yang dimiliki oleh perusahaan adalah asset yang secara sah dimiliki oleh perusahaan sesuai aturan syariah (halal) tidak terdapat unsur yang merugikan orang lain dan didapat dari jalan yang batil (mencuri, menipu, perjudian, dan sebagainya). 
6. Pemanfaatan sesuai hak

Pemanfaatan harta pribadi dengan mengabaikan kepentingan yang lebih luas bagi masyarakat bertentangan dengan jiwa Islam. Asset yang ada diperusahaan digunakan semaksimal mungkin untuk kepentingan kesejahteraan semua pihak (stakeholders) tidak hanya segelintir orang saja (shareholder).

7. Kepentingan kehidupan

Karena persoalan pengawasan dan pembagian harta tidak timbul setelah kematian pemiliknya, maka kepentingan bagi mereka yang masih hidup harus terjamin dengan mempraktekkan hukum waris Islam. Bahwa asset yang tercatat dalam pembukuan Islam memiliki ahli waris dalam hal ini adalah pemilik perusahaan.

Secara umum tujuan dari syariah menurut Al-Ghazali dalam Chapra (2000),adalah sebagai upaya untuk mewujudkan kesejahteraan bagi umat manusia yang terletak pada : mengamankan keyakinan atau agama, mengamankan diri manusia itu sendiri, mengamankan otak dan pikirannya, mengamankan keturunan dan generasi mudanya dan mengamankan harta kekayaannya.

\section{Asset (Harta)}

Dalam Quran surat An-Nisa ayat 132 berbunyi : “Dan kepunyaan Allah-lah apa yang di langit dan apa yang di bumi. Cukuplah Allah sebagai Pemelihara.'Kemudian dalam surat AlBaqarah ayat 29 disebutkan :"Dia-lah Allah, yang menjadikan segala sesuatu yang ada di bumi untuk kamu." Berdasarkan surat tersebut dapat disimpulkan bahwa harta adalah sesuatu yang dimiliki dan yang mempunyai manfaat dan berguna bagi kehidupan manusia.

Harta dalam bahasa Arab disebut harta disebut al-mal dan bentuk plural atau jama'nya adalah al-amwal dan secara etimologi kata al-mal berarti condong, miring dan juga berpaling.Dalam Mukhtar al-Qamus dan kamus al-Muhith, kata al-maal diartikan sebagai apa saja yang dimiliki. Dalam Mu'jam al-Wasith, maal itu ialah segala sesuatu yang dimiliki seseorang atau kelompok, seperti perhiasan, barang dagangan, bangunan, uang, dan hewan.Sedangkan menurut Abdul Karim Zaidan dalam Mahyuddin Khalid (http://www.slideshare.net/emkay84) harta didefinisikan : "Sesuatu yang boleh dimiliki atau akan dimiliki dimasa depan dan berfaedah kepada manusia."

Menurut Abdul Salam al-Abadi dalam Muhammad Jamhuri (http://www.slideshare.net/Jamhuri), "kepemilikan sebagai hak khusus manusia terhadap barang yang diizinkan untuk memanfaatkan dan mengalokasikannya tanpa batas hingga terdapat alasan yang melarangnya". Secara terminologi kepemilikan adalah hubungan manusia dengan sesuatu (harta) yang memungkinkan untuk memanfaatkannya dan menggunakannya dan mencegah pihak lain menggunakannya.

\section{METODE PENELITIAN}

Metode penulisan ini berdasarkan kajian pustaka melalui berbagai literature dengan tujuan menginformasikan kepada pembaca (informative research). Analisis pada penelitian ini menggunakan desain penelitian deskriptif (descriptive research) yaitu prosedur penelitian yang menghasilkan data desriptif berupa kata-kata tertulis dari orang-orang dan perilaku yang diamati, didukung dengan studi literatur atau studi kepustakaan berdasarkan pendalaman kajian pustaka.

\section{PEMBAHASAN}

\section{Konsep Dasar Kepemilikan Dalam Islam}

Dalam Al-quran dasar kepemilikan diatur dalam surat:

1. QS. Al Maidah: 120, "Kepuyaan Allah lah kerajaan di langit dan di bumi dan apa yang ada di dalamnya,dan Dia maha kuasa atas segala sesuatu". 
2. QS. Al-Hadid: 7, "Berimanlah kamu kepada Allah dan Rasul-Nya dan nafkahkanlah sebagian dari hartamu yang Allah telah menjadikan kamu menguasainya. Maka orang-orang yang beriman di antara kamu dan menafkahkan (sebagian) dari hartanya memperoleh pahala yang besar."

3. QS. Nuh: 12: "Maka aku katakan kepada mereka:"Mohonlah ampun kepada Tuhanmu, sesungguhnya Dia adalah Maha Pengampun". Niscaya Dia akan mengirimkan hujan kepadamu dengan lebat, dan membanyakkan harta dan anakanakmu, dan mengadakan untukmu kebun-kebun dan mengadakan (pula didalamnya) untukmu sungai-sungai."

Menurut Mannan (1985) dalam Adnan (2005:26), kepemilikan terhadap harta diperbolehkan dengan memenuhi beberapa syarat:

1. Pemanfaatan harta benda secara terus menerus

2. Pembayaran zakat sebanding dengan harta benda yang dimiliki

3. Penggunaan harta benda secara berfaedah

4. Penggunaan harta benda tanpa merugikan orang lain

5. Memiliki harta benda dengan sah

6. Penggunaan harta benda tidak dengan cara boros, serakah atau pelit

7. Penggunaan harta benda dengan tujuan memperoleh keuntungan atas haknya

8. Penerapan hukum waris yang tepat seperti yang sudah diatur

\section{Kepemilikan Asset Tetap Dalam Pandangan Konvensional}

Kepemilikan harta (asset) dalam pandangan konvensional tidak dibatasi kepemilikannya artinya seseorang dapat memiliki dan menguasai asset bila mana mempunyai kemampuan untuk memilikinya. Subekti (1982:67) menyatakan seseorang yang mempunyai hak eigendom (milik) atas suatu benda dapat berbuat apa saja dengan benda itu (menjual, menggadaikannya, memberikan, bahkan merusak), asal saja ia tidak melanggar undang-undang dan hak orang lain.Individu adalah pemilik hak mutlak dari asset yang dimilikinyatermasuk menggunakan asset tersebut. Pembatasan kepemilikan dan penggunaan asset dikonvensional hanya dibatasi oleh peraturan (undang-undang) saja dan etika moral individu.

Asset dalam akuntansi konvensional terbagi atas dua bagian yaitu aktiva lancar dan aktiva tetap. Aktiva menurut definisi SAK (2002:13) diartikan Aktiva adalah sumberdaya yang dikuasi oleh perusahaan sebagai akibat dari peristiwa masa lalu dan dari mana manfaat ekonomi dimasa depan diharapkan akan diperoleh perusahaan. Aktiva tetap didefinisikan SAK 2002, paragraf ke-5 adalah : Aset tetap berwujud yang diperoleh dalam bentuk siap pakai atau dengan dibangun dahulu, yang digunakan dalam operasi perusahaan, tidak dimaksudkan untuk dijual dalam rangka kegiatan normal perusahaan dan mempunyai masa manfaat lebih dari satu tahun.

Sedangkan pengertian asset menurut Belkaoui (1993:393): "Asset are probable future economic benefit, or controlled by a particular entity as a result of past event". Kieso (2011) mengartikan asset sebagai:"tangible asset that are held use in production or supply of goods and servise, for rental to other, or administrative purpose; they are expected to be used during more than one period.

Berdasarkan uraian diatas dapat disimpulkan bahwa asset terbagi atas dua bagian yaitu asset lancar dan asset tetap. Asset lancar digunakan dalam siklus operasional perusahaan dengan umur tidak lebih dari satu tahun, sedangkan asset tetap digunakan dalam operasional perusahaan lebih dari satu tahun. Aktiva tetap digunakan oleh perusahaan untuk menghasilkan barang dan jasa atau disewa dengan pihak lain atau digunakan untuk administrasi perusahaan. Aktiva lancar terdiri dari antara lain kas, piutang, persediaan, beban dibayar dimuka. Sedangkan aktiva tetap antara lain adalah tanah, bangunan, kendaraan, peralatan. Pembagian asset lancar dan asset tetap berlaku juga dalam akuntansi syariah. 


\section{Pengakuan Asset Dalam Akuntansi Syariah}

Dalam hal kepemilikan harta dalam Islam, Rahman (1995:315), mengatakan bahwa masyarakat diakui hak penggunaannya, dalam hal ini disebut hak kepemilikan, jika dia menghargai hak-hak masyarakat dan menjalankan kewajibannya. Masyarakat diberikan hak untuk memiliki harta sepanjang harta tersebut diperoleh sesuai dengan aturan syari', tidak didapat dari hal-hal yang melanggar syari' seperti dari mencuri, menipu, merampok, perjudian, riba, dan sebagainya. Dalam hadist Rasullulah bersabda : "Sesungguhnya Allah suka kalau Dia melihat hamba-Nya berusaha mencari barang dengan cara yang halal". (HR. At-Thabrani). Dalam hadist lainnya Rasullulah bersabda : "Barang siapa mengumpulkan harta dari jalan haram, lalu dia menyedekahkannya, maka dia tidak mendapatkan pahala, bahkan dosa." (HR. Huzaimah).

Allah mempunyai aturan yang dituangkan dalam Al-Quran dan Hadits Nabi Muhammad SAW sebagai pedoman dalam melaksanakannya diikuti oleh aturan-aturan yang dibuat para ulama bila tidak dijelaskan dalam Al-Quran dan Hadist. Aturan Allah SWT dikenal dengan hukum Syari'ah yang mengatur segala kehidupan didunia ini termasuk kepemilikan asset. Kepemilikan asset dalam Islam harus tunduk kepada hukum yang telah ditetapkan.Nabhani (68:1996), terjemahan menyatakan Allah memberikan pemilikan tersebut kepada seseorang, yang merupakan konsekuensi dari sebab-sebab yang mengikuti aturan syara'. Selanjutnya Nabhani (68:1995) mengatakan, "oleh karena itu, kepemilikan tersebut hakikatnya merupakan penyerahan hak milik atas barang-barang tertentu dari As-Syari' (Allah) yang diberikan kepada seseorang dalam suatu kelompok (community), dimana kepemilikan tersebut tidak akan pernah ada, kalau bukan karena adanya penyerahan kepemilikan- dari Allah (As-Syari')-tersebut."

Pengakuan asset dalam akuntansi syariah adalah asset yang dimiliki secara halal artinya halal secara zat-nya dan halal cara memperolehnya. Faktor-faktor yang menyebabkan terjadinya kepemilikan dalam syariah ada empat macam yaitu: (http://dinilidari.blogspot.com)

1. Kepenguasaan terhadap barang-barang yang diperbolehkan

2. Akad

3. Penggantian

4. Turunan dari sesuatu yang dimiliki.

Kepemilikan asset dicatat dalam pembukuan pada saat transaksi (akad) yaitu berpindahnya kepemilikan dari penjual kepada pembeli.Allah berfirman (Al Maa-Idah, 1) : " Hai orang-orang beriman, penuhilah aqad-agad itu”. Rukun dan syarat sah akad (Nurhayati, 2011:72) terdiri dari 3 (tiga) yaitu:

1. Pelaku yaitu para pihak yang melakukan akad

2. Objek akad merupakan konsekuensi tertentu yang harus ada dengan dilakukannya suatu transaksi tertentu

3. Ijab kabul merupakan kesepakatan dari para pelaku dan menunjukkan mereka saling ridho.

\section{Pengukuran Nilai Asset}

Asset (harta) dilaporkan dalam laporan keuangan di neraca. Kaedah pelaporan harta ini mengikuti kaedah akuntansi yang selama ini berlaku karena tidak ada larangannya (sesuatu itu diperbolehkan bila tidak ada larangannya). Menurut Nurhayati (2011:100) asset dapat dicatat dengan 3 (tiga) nilai yaitu:

1. Biaya Historis (Historical Cost)

Asset dicatat sebesar pengeluaran kas (atau setara kas) yang dibayar atau sebesar nilai wajar dari imbalan (consideration) yang diberikan untuk memperoleh asset tersebut

2. Biaya Kini (Current Cost)

Asset dinilai dalam jumlah kas (setara kas) yang seharusnya dibayar bila asset yang sama atau setara aset diperoleh sekarang 
3. Nilai Realisasi/Penyelesaian (Realizable/settlement value)

Asset dinilai dalam jumlah kas (setara kas) yang dapat diperoleh sekarang dengan menjual asset dalam pelepasan normal (ordery disposal)

\section{Asset - Asset Terlarang dalam Islam}

Kepemilikan terhadap harta (asset) dilarang dalam Islam karena zat-nya haram ataupun cara perolehannya tidak sesuai dengan syari'ah yaitu:

1. Kepemilikan yang dilarang karena zat-nya seperti babi, mimuman memabukan, narkoba.

Al-quran menjelaskan dalam surat An-Nahl ayat 115 : "Sesungguhnya Allah hanya mengharamkan atasmu (memakan) bangkai, darah, daging babi dan apa yang disembelih dengan menyebut nama selain Allah; tetapi barangsiapa yang terpaksa memakannya dengan tidak menganiaya dan tidak pula melampaui batas, maka sesungguhnya Allah Maha Pengampun lagi Maha Penyayang. " Kemudian dalam hadist Rasullulah bersabda: "Sesungguhnya Allah apabila mengharamkan sesuatu juga mengharamkan harganya" (HR. Ahmad).

2. Diperoleh dari jalan Riba

Allah SWT melarang hambanya melakukan riba dengan alasan apapun juga termasuk kepemilikan asset yang didapat dari riba. Al-quran surat surat Ar-Rum ayat 39, menjelaskan: "Dan sesuatu riba (tambahan) yang kamu berikan agar dia bertambah pada harta manusia, maka riba itu tidak menambah pada sisi Allah. Dan apa yang kamu berikan berupa zakat yang kamu maksudkan untuk mencapai keridhaan Allah, maka (yang berbuat demikian) itulah orang-orang yang melipat gandakan (pahalanya)." Kemudian dalam Al-quran surat Al-baqarah ayat 278, Allah berfirman : "Hai orang-orang yang beriman, bertakwalah kepada Allah dan tinggalkan sisa riba (yang belum dipungut) jika kamu orang-orang yang beriman.

3. Diperoleh karena menipu, membohong

Allah melarang hambanya melakukan kebohongan termasuk memperoleh harta dengan cara yang batil. Firman Allah dalam surat An-Nahl ayat 105: "Sesungguhnya yang mengada-adakan kebohongan, hanyalah orang-orang yang tidak beriman kepada ayat-ayat Allah, dan mereka Itulah orang-orang pendusta." Dalam hadist Rasullulah bersabda : "Barang siapa menipu, dia bukan dari golonganku." (HR-Abu Hurairah r.a)Digunakan untuk merusak dan menimbulkan kerugian kepada orang lain

4. Harta diperoleh dari perjudian

Kepemilikan harta karena dari judi juga dilarang dalam Islam. Dalam surat AlMaidah ayat 90 Allah berfirman: "Hai orang-orang yang beriman, Sesungguhnya (meminum) khamar, berjudi, (berkorban untuk) berhala, mengundi nasib dengan panah, adalah Termasuk perbuatan syaitan. Maka jauhilah perbuatan-perbuatan itu agar kamu mendapat keberuntungan."

5. Harta yang didapat dari penyuapan

Praktek penyuapan dilarang dalam Islam termasuk kepemilikan asset dari hasil penyuapan itu sendiri. Allah berfirman dalam surat Al-Baqarah ayat 188 : Dan janganlah sebahagian kamu memakan harta sebahagian yang lain di antara kamu dengan jalan yang bathil dan (janganlah) kamu membawa (urusan) harta itu kepada hakim, supaya kamu dapat memakan sebahagian daripada harta benda orang lain itu dengan (jalan berbuat) dosa, Padahal kamu mengetahui."

6. Harta diperoleh karena tidak sahnya akad

Kepemilikan harta menjadi haram apabila berasal dari akad transaksi yang tidak sah. Misalnya terjadi persyaratan yaitu harta ini dapat dimiliki bila akad kedua terpenuhi. Hadist riwayat Al-Thabrani menyebutkan : "Rasullulah SAW melarang jual beli bersyarat".Pelarangan kepemilikan harta juga dilarang dari akad lebih dari satu misalnya akad sewa beli (leasing). Hadis ririwayatkan 'Amr ibn Syu'aib 
r.a.,mengatakan : "Tidak dihalalkan meminjam dan menjual, dua syarat dalam satu transaksi jual beli, keuntungan yang belum dapat dijamin, dan menjual sesuatu yang bukan milikmu."

\section{Macam-macam Kepemilikan Dalam Islam}

Macam-macam kepemilikan dalam Islam yang dikutip dari Syifa Mukrimaa (www.slideshare.net/SyifaMukrimaa) adalah sebagai berikut:

1. 1. Al Milk At Tamm

Kepemilikan sempurna adalah kepemilikan seseorang terhadap barang dan juga manfaatnya sekaligus.

2. Al Milk An Naqish

Konsep kepemilikan yang tidak sempurna, artinya bahwa hanya melibatkan aspek pengurusan dan penyeliaan Al Milk Al 'Ain (kepemilikan atas materinya saja) Al Milk An Naqish Al Milk Al Manfaah (kepemilikan atas manfaatnya saja)

3. Kepemilikan Individu

Kepemilikan Individu (private property)adalah harta yang dimiliki oleh seseorangyang ia dapatkan dengan cara yang sahmenurut Islam dan hak manfaat atas hartatersebut hanya dapat digunakan olehindividu tersebut saat masih hidup sesuaisyar'i

4. Kepemilikan Umum (public utility)

Kepemilikan umum adalah izin Syari' kepadasuatu komunitas masyarakat untuk samasama memanfaatkan suatu barang atau harta.Benda-benda yang termasuk kedalam kategorikepemilikan umum adalah benda-benda yangtelah dinyatakan oleh Asy-Syari' memangdiperuntukan untuk suatu komunitasmasyarakat.

5. Kepemilikan Negara (state property)

Kepemilikan Negara adalah harta yangmerupakan hak seluruh kaum muslim,sementara pengelolaannya menjadiwewenang Negara.Negara membutuhkan hak milik untukmemperoleh pendapatan, sumberpenghasilan dan kekuasaan untukmelaksanakan kewajiban-kewajibannya, sedangkan manfaatdari materi, benda atau barangnya itutidak dirasakan oleh pemiliknya.

\section{Sebab-SebabPengembangan Kepemilikan}

Sebab-sebab kepemilikan harta terbatas pada lima sebab berikut ini (http://tawakaltawakal.blogspot.com):

1. Bekerja

2. Pewarisan

3. Kebutuhan akan harta untuk menyambung hidup

4. Pemberian harta untuk rakyat

5. Harta-harta yang diperoleh oleh seseorang tanpa mengeluarkan kompensasi berupa harta atau tenaga.

\section{Zakat atas Asset (Harta) Perusahaan}

Zakat dapat diartikan kadar harta tertentu yang diberikan kepada yang berhak menerimanya dengan beberapa syarat (Rasjid, 2010:192). Hukum zakat adalah wajib (fardhu ain) sesuai dengan firman Allah SWT (An-Nisa: 77): "Dirikan shalat dan dan tunaikanlah zakat"Rasullulah bersabda : "Islam ditegakkan diatas lima pondasi ; ........... (3) Menunaikan zakat, ......." (HR. Ibnu Umar r.a.). Zakat berasal dari harta yang telah cukup persyaratannya. Allah SWT berfirman (At-Taubah: 103): "Ambillah zakat dari sebagian harta mereka, dengan zakat itu kamu membersihkan dan mensuci mereka dan berdoalah untuk mereka. "Allah juga berfirman (Adzzariyat:19): "Dalam harta mereka ada hak untuk orang miskin yang meminta dan yang tidak berkecukupan walaupun tidak meminta".

Menurut Rasjid (2010:193) benda yang wajib dizakatkan adalah binatang ternak, emas dan perak, biji makanan yang mengenyangkan, buah-buahan, harta perniagaan. Menurut Hafidhuddin (2002:92) dalam perekonomian modern yang dapat dizakatkan terbagi atas dua yaitu zakat yang 
dikenakan atas flows dan zakat atas stocks. Flows adalah zakat yang dikenakan terhadap berbagai aktifitas ekonomi yang dapat dilakukan dalam waktu, jam, hari, bulan dan tahun tergantung dengan akadnya. Sedangkan stocks adalah networth, yaitu hasil kotor dikurangi keperluan keluarga dari orang per orang yang harus dikenakan zakat pada setiap tahunnya sesuai nishab.

Dalam hal zakat perusahaan berdasarkan hasil Muktamar Internasional pertama di Kuwait, 29 Rajab $1404 \mathrm{H}$, perusahaan termasuk ke dalam syakhsan i'ibarat(badan hukum yang dianggap orang) dalam Hafidhuddin (2002:101). Dalam UU No. 38 tahun 1999, tentang Pengelolaan Zakat, dijelaskan bahwa objek zakat yang wajib dikeluarkan adalah zakat atas perdagangan dan perusahaan (Bab IV, pasal 11).

Zakat terhadap asset tetap perusahaan yang produktif atau asset yang digunakan untuk menghasilkan pendapatan adalah zakat perusahaan itu sendiri. Hal ini berdasarkan pendapat yang dikemukakan oleh Abu Ubaid dalam Hafidhuddin (2002:102) menyatakan bahwa: "apabila Anda telah sampai batas waktu untuk membayar zakat (1 tahun), perhatikan apa yang telah engkau miliki, baik berupa uang (kas) atapun barang yang siap dijual (persediaan), kemudian nilailah dengan uang, dan hitunglah utang-utangmu atas apa yang engkau miliki." Dalam perhitungan zakat perusahaan dapat diilustrasikan sebagai sebagai berikut:

\section{Formula perhitungan zakat perusahaan:}

Zakat Perusahaan $=($ Jumlah Aktiva Lancar - Hutang Lancar + Keuntungan Bersih - nilai hisab 85 gram emas) x $2,5 \%$

Aktiva tetap perusahaan tidak dihitung zakatnya karena diasumsikan aktiva tetap digunakan oleh perusahaan untuk menghasilkan barang dan jasa dalam siklus operasionalnya. Pendapatan bersih hasil dari penjualan barang dan jasa tersebut dikenakan zakat sesuai dengan formula diatas. Hutang jangka panjang tidak digunakan dalam penggurangan hutang karena dalam prinsip keuangan bahwa hutang jangka panjang digunakan untuk pembiayaan jangka panjang (misalnya pembelian asset tetap). Oleh karena itu aktiva tetap dan hutang jangka panjang tidak digunakan dalam perhitungan nilai zakat perusahaan.

Zakat perusahaan tidak dikenakan bila mana dalam perhitungan dengan menggunakan formula diatas ternyata menghasilkan angka yang negatif. Zakat perusahaan yang dihitung benarbenar bebas dari hutang jangka pendek yang digunakan oleh perusahaan dalam membiayai operasional jangka pendeknya.

Sebagai ilutrasi perhitungan sebagai berikut:

Tabel 1

Neraca PT. ABC Per 31 Desember 20XX (Milyar Rupiah)

\begin{tabular}{|c|c|c|c|}
\hline Aktiva & & Passiva & \\
\hline Aktiva Lancar & 20 & Hutang Lancar & 10 \\
\hline \multirow{4}{*}{ Aktiva Tetap } & 30 & Hutang Jangka Panjang & 25 \\
\hline & & Modal Saham & 5 \\
\hline & & Laba ditahan & 2 \\
\hline & & Laba tahun berjalan & 8 \\
\hline Total Aktiva & 50 & Total Passiva dan Modal & 50 \\
\hline
\end{tabular}

Zakat perusahaan $=(20-10+8-0.03) \times 2.5 \%=0,449 \mathrm{M}$

(Asumsi hisab tidak dikenakan zakat $\mathrm{Rp} 0.03 \mathrm{M}$ )

Harta yang dimiliki manusia (perseorangan atau kelompok) wajib di zakatkan seperti rumah, villa, kendaraan, tanah, dan lain-lain dengan tujuan menyimpan yang sewaktu-waktu dapat diuangkan (bukan yang digunakan untuk kehidupan sehari-hari) dengan persyaratan adalah sebagai berikut (Al Faridy, 1996): 
1. Milik Penuh (Almilkuttam)

Harta tersebut berada dalam kontrol dan kekuasaanya secara penuh, dan dapat diambil manfaatnya secara penuh. Harta tersebut didapatkan melalui proses pemilikan yang dibenarkan menurut syariat Islam, seperti : usaha, warisan, pemberian negara atau orang lain dan cara-cara yang sah. Sedangkan apabila harta tersebut diperoleh dengan cara yang haram, maka zakat atas harta tersebut tidaklah wajib, sebab harta tersebut harus dibebaskan dari tugasnya dengan cara dikembalikan kepada yang berhak atau ahli warisnya.

2. Berkembang

Harta tersebut dapat bertambah atau berkembang bila diusahakan atau mempunyai potensi untuk berkembang.

3. CukupNishab

Artinya harta tersebut telah mencapai jumlah tertentu sesuai dengan ketetapan syara'. sedangkan harta yang tidak sampai nishabnya terbebas dari Zakat

4. Lebih Dari Kebutuhan Pokok (Alhajatul Ashliyah)

Kebutuhan pokok adalah kebutuhan minimal yang diperlukan seseorang dan keluarga yang menjadi tanggungannya, untuk kelangsungan hidupnya. Artinya apabila kebutuhan tersebut tidak terpenuhi yang bersangkutan tidak dapat hidup layak. Kebutuhan tersebut seperti kebutuhan primer atau kebutuhan hidup minimum (KHM), misal, belanja seharihari, pakaian, rumah, kesehatan, pendidikan, dsb.

5. Bebas Dari hutang

Orang yang mempunyai hutang sebesar atau mengurangi senishab yang harus dibayar pada waktu yang sama (dengan waktu mengeluarkan zakat), maka harta tersebut terbebas dari zakat.

6. Berlalu Satu Tahun (Al-Haul)

Maksudnya adalah bahwa pemilikan harta tersebut sudah belalu satu tahun. Persyaratan ini hanya berlaku bagi ternak, harta simpanan dan perniagaan. Sedang hasil pertanian, buah-buahan dan rikaz (barang temuan) tidak ada syarat haul.

Dari persyaratan zakat diatas bahwa aktiva perusahaan tidak dapat dikatagorikan sebagai barang (asset) yang dikenakan zakat. Asset tetap perusahaan tidak bisa berkembang seperti layaknya modal dan bukan merupakan kelebihan dari kebutuhan pokok perusahaan. Asset tetap digunakan oleh perusahaan semata-mata untuk menghasilkan barang dan jasa. Kieso (2011:512) mendefinisikan asset tetap adalah "as tangible assets that are held for use in production or supply of goods and servises, for rentals to others, or for administrative purpose; they are expected to be used during more than one period." Jadi zakat atas asset tetap perusahaan telah termasuk dalam perhitungan zakat perusahaan secara keseluruhan.

\section{PENUTUP}

Kepemilikan harta (asset tetap) oleh individu sipatnya terbatas dalam arti bahwa harta itu hakekatnya adalah milik Allah SWT. Kepemilikan harta diakui Islam sepanjang harta tersebut tidak membahayakan masyarakat, termasuk didalamnya kepemilikan atas tanah, bangunan, kendaraan, peralatan, dan asset yang lainnya oleh individu." Dan berikanlah kepada mereka sebagian harta Allah yang dikaruniakan Nya kepadamu.” (QS: An-Nur, 33). Makna yang tersirat adalah bahwa harta yang ada pada diri manusia adalah kepunyaan Allah SWT dan hanya merupakan titipan saja dimana dalam harta tersebut itu terdapat hak orang lain yang mesti dikeluarkan dalam bentuk zakat.

Penggunaan asset tetap hanya diijinkan untuk kemashalatan (kebaikan) saja. Allah berfirman dalam Al-Quran (An-Nisaa':29) : “ Janganlah kamu saling memakan harta sesamamu dengan jalan yang batil". Dan setiap penggunaan asset akan diminta pertanggungjawaban dikemudian hari sesuai dengan hadist Rasullulah "Tidak akan bergeser dua telapak kaki seorang 
hamba pada hari kiamat sampai dia ditanya (dimintai pertanggungjawaban) tentang umurnya kemana dihabiskannya, tentang ilmunya bagaimana dia mengamalkannya,tentang hartanya; dari mana diperolehnya dan ke mana dibelanjakannya, serta tentang tubuhnya untuk apa digunakannya" (HR. At-Tirmidzi).

Kepemilikan asset dicatat dalam akuntansi syariah berdasarkan kaedah (aturan syariah) yaitu pemanfaatan harta benda secara terus menerus, pembayaran zakat sebanding dengan harta benda yang dimiliki, penggunaan harta benda secara berfaedah, penggunaan harta benda tanpa merugikan orang lain, memiliki harta benda dengan sah, penggunaan harta benda tidak dengan cara boros, serakah atau pelit, penggunaan harta benda dengan tujuan memperoleh keuntungan atas haknya, penerapan hukum waris yang tepat seperti yang sudah diatur(Mannan ,1985 dalam Adnan, 2005:26). Sedangkan kepemilikan asset konvensional bersifat tidak terbatas dan hanya dibatasi oleh undang-undang serta etika moral.

Zakat yang dikeluarkan atas asset tetap perusahaan termasuk didalam zakat perusahaan itu sendiri. Dalam prinsip akuntansi aktiva tetap digunakan untuk menghasilkan barang dan jasa yang merupakan sumber penerimaan perusahaan. Artinya zakat atas asset tetap perusahaan telah dihitung dalam perhitungan zakat perusahaan.

\section{REFERENSI}

Al-Qur'An Al Karim dan Terjemahan. 1996. Semarang: CV. Toha Putra

Al Faridy, Hasan Rifa'i. 1996. Panduan Zakat Praktis. Jakarta: Dompet Dhuafa Republika

Adnan, Akhyar. 2005. Akuntansi Syariah: Arah, Prospek dan Tantangan. Yogyakarta: UII Press

Ath-Thahthawi, Syaik Ali Ahmad Abdul 'Aal. 2007. Larangan Dalam Islam dan Fatwa-Fatwa Syaikh Muhammad bin Shalih Al-Utsaimin. Terjemahan. Jakarta:Pustaka at-Tazkia

Burhanuddin, S. 2011. Hukum Bisnis Syariah. Yogyakarta: UII Press

Capra, M, Umar. 2000. The Future of Economic, an Islamic Perspectives. London: The Islamic Foundation.

Capra, M, Umar. 2001. What is Islamic Economics?. Saudi Arabia; Islamic Research and Training Institute

Djuanda, Gustian, at al. 2006. Pelaporan Zakat, Pengurangan Pajak Penghasilan. Jakarta: Rajagrafindo Persada.

Hafidhuddin, Didin. 2002. Zakat Dalam Perekonomian Modern. Depok: Gema Insani

Harahap, Sofyan, S.2001. Menuju Perumusan Teori Akuntansi Islam. Jakarta: Pustaka Quantum Prima.

Ikatan Akuntan Indonesia. 2002.Standar Pelaporan KEuangan.Jakarta: Salemba Empat

Kieso, Weygandt, and Warfield (2011), Intermediate Accounting, IFRS Edition. New York: Jhon Wiley \& Sons, Inc.

Mannan, Abdul. 1997. Ekonomi Islam, Teori dan Prakter. Terjemahan. Solo: Amanah Bunda Sejahtera.

Mirza, Malik; Baydoun Nabil. 1999. Do Islamic Societies Need Their Own Accounting and Reporting Standards?. Journal of the Academy of Business Administration (Fall 1999), vol. 4, No. 2, pp. 39-45.

Mulawarman, Aji Dedi. 2006. Menyibak Akuntansi Syariah, Rekonstruksi Teknologi Akuntansi Syariah dari Wacana Aksi. Yogyakarta: Kreasi Wacana

Nabhani, Taqyuddin An. 1990. Membangun Sistem Ekonomi Alternatif, Persfektif Islam. Terjemahan Maghfur Wachid. Surabaya: Risalah Gusti

Nawawi, Ismail. 2009. Ekonomi Islam, Perspektif Teori, Sistem dan Aspek Hukum. Surabaya: CV. Putra Media Nusantara

Qardhawi, Yusuf. 1997. Peran Nilai dan Moral Dalam Perekonomian Islam. Terjemahan Didin Hafidhuddin. Jakarta: Robbani Press

Rasjid, Sulaiman. 2010. Fiqh Islam. Bandung: Sinar Baru Algensindo.

Rahman, Afzalur. 1995. Dokrin Ekonomi Islam, Jilid 2. Yogyakarta: PT. Dana Bhakti Wakaf 
Sularno, M. 2003. Konsep Kepemilikan Dalam Islam, Kajian dari Aspek Filosofis dan Potensi Pengembangan Ekonomi Islam. Al-Mawarid Edisi IX, hal 80-87.

Sri Nurhayati; Wasilah. 2011. Akuntansi Syariah di Indonesia, Edisi 2 Revisi. Jakarta: Salemba Empat

Subekti. 1986. Pokok-Pokok Hukum Perdata. Jakarta: Intermasa.

Taheri, Mohammad, R.2001. The Basic Principles of Islamic Economy and Their Effects on Accounting Standards. www.Islamic.accounting.com

Yusanto, M, Ismail; Yunus, M, Arif. 2009. Pengantar Ekonomi Islam. Bogor: Al-Azhar Press

Wan Yusoh, Wan Ismail.2001. Islamic Accounting, Working Paper. Internatinal Conference on Islamic Banking and Finance. LAP dan EKABA FE Trisakti. 